Perkembangan E-Learning Sebagai... (Rochman Hadi Mustofa, Henni Riyanti)

\title{
PERKEMBANGAN E-LEARNING SEBAGAI INOVASI PEMBELAJARAN DI ERA DIGITAL
}

\author{
Oleh : Rochman Hadi Mustofa, Henni Riyanti \\ (Universitas Muhammadiyah Surakarta, Universitas PGRI Palembang) \\ e-mail:rhm342@ums.ac.id, henniriyanti@univpgri-palembang.ac.id
}

\begin{abstract}
Abstrak
Tujuan dari artikel ini adalah untuk menganalisa perkembangan e-learning sebagai sebuah pembelajaran modern yang efektif. Perkembangan teknologi yang serba canggih saat ini telah mendorong berbagai jenis adaptasi dalam kehidupan manusia termasuk e-learning. Pertama akan dibahas pola dari e-learning, contoh penerapan e-learning dalam pembelajaran termasuk pihak yang terlibat, terakhir akan dijabarkan strategi penerapan e-learning untuk mencapai pembelajaran modern yang efektif.
\end{abstract}

Kata Kunci: E-Learning, Inovasi Pembelajaran, Pembelajaran Modern

\section{E-LEARNING DEVELOPMENT AS A LEARNING INNOVATION IN DIGITAL ERA}

\begin{abstract}
The purpose of this article is to analyze the development of e-learning as an effective modern learning. The development of sophisticated technology that has now encouraged various types of adaptation in human life, including e-learning. First will be discussed various definitions and positive benefits of e-learning, then the authors describe the pattern of e-learning, examples of the application of elearning in learning including those involved, and finally will be elaborated on elearning implementation strategies to achieve effective modern learning.
\end{abstract}

Keyword: E-Learning, Learning Innovation, Modern Learning

\section{A. PENDAHULUAN}

Pesatnya perkembangan teknologi canggih saat ini mendorong terjadinya integrasi besar-besaran pada berbagai aspek kehidupan, termasuk dalam dunia pendidikan. Penerapan Teknologi Informasi dan Komunikasi (TIK) dalam dunia pendidikan melahirkan evolusi pembelajaran dari tradisional menjadi pembelajaran online seperti e-learning, pembelajaran berbantukan komputer (CAI), pembelajaran berbasis Audio-Visual (AVA), dan pembelajaran berbasis multimedia. Berkat kecanggihan teknologi saat ini, sumber belajar dapat diperoleh dengan mudah dan pembelajaran tidak lagi dibatasi oleh jarak, lokasi, atau 
kehadiran secara fisik, sehingga e-learning disebut juga sebagai invisible classroom (Tham \& Werner, 2005). Secara khusus penulis akan membahas pada perkembangan e-learning sebagai suatu inovasi pembelajaran modern yang lebih efektif.

E-learning merupakan sebuah peluang dan inovasi baru yang menarik dalam dunia pendidikan. E-learning mampu memberi dampak yang signifikan dalam mengatasi keterbasan belajar dan memperluas cakupan sumber belajar. Darmawan (2014:17) mengungkapkan bahwa e-learning memungkinkan pembelajaran bisa lebih mudah dikelola khususnya dari segi materi, penempatan, pengelolaan, dan penilaian serta setting lingkungan dan kondisi pembelajaran yang dibutuhkan.

Dalam membangun sebuah lingkungan e-learning, perlu diperhatikan aspek sosial dan teknologi serta organisasi dan personal yang sangat berpengaruh terhadap kebutuhan sistem dan teknologi serta bahan untuk membangunnya. Lebih jauh lagi, pimpinan lembaga atau institusi pendidikan harus bekerja sama dengan bagian keuangan, ahli IT dan fasilitas, serta komitmen guru atau pengajar untuk menyelenggarakan sebuah pembelajaran berbasis e-learning (Marshall, 2012). Hanya dengan menjalankan langkah tersebut pembelajaran yang efektif melalui e-learning dapat tercapai. Institusi pendidikan tinggi harus bersiap menghadapi tingginya tuntutan kualitas pembelajaran melalui pemanfaatan teknologi, seperti kemampuan digital dalam pendidikan dan belajar teknologi global masa depan yang berkelanjutan untuk menjamin keberhasilan di masa mendatang (Ossiannilsson, 2012).

Apabila dikaitkan dengan pembelajaran yang efektif, tujuan akhir $e$-learning adalah agar siswa sebagai penerima pesan memperoleh apa yang diharapkan oleh mereka dan memiliki pengetahuan, keterampilan, dan melakukan tindakan atau diajak untuk berubah, baik secara pemikiran, perilaku, kondisi fisik, kesehatan, ekonomi, sosial, dan aktivitas, serta peran manusia yang lainnya (Darmawan, 2014:18). Sebagai contoh di Tanzania, melalui dukungan perusahaan teknologi internasional dan organisasi non-profit telah mengembangkan proyek e-learning ICT kepada lebih dari satu juta siswa sekolah menengah pertama (eLearning 
Africa, 2011), yang berkontribusi terhadap pemberdayaan populasi penduduk negara tersebut. Menyadari hal tersebut pemerintah mengembangkan kebijakan untuk memeratakan penyebaran infrastruktur yang mendukung pembelajaran ICT dan teknologi lain yang terkait dengan fokus menangani kebutuhan sosial. Dengan meluasnya pembelajaran ICT tersebut pada sektor formal dan informal mendorong peluang nilai balik pendidikan atau rate of return menjadi semakin luas (Male \& Pattinson, 2011).

\section{B. METODOLOGI PENELITIAN}

Metode yang digunakan dalam artikel Perkembangan E-Learning Sebagai Inovasi Pembelajaran Di Era Digital menggunakan metode atau pendekatan kepustakaan. Menurut Zed (2003:3) studi pustaka atau kepustakaan dapat diartikan sebagai serangkaian kegiatan yang berkenaan dengan metode pengumpulan data dan pustaka, membaca dan mencatat serta mengolah bahan penelitian. Dalam penelitian pustaka ini dilakukan pengumpulan data dengan menelaah beberapa artikel-artikel secara online, buku, dokumen, serta sumbersumber data lainnya yang dianggap relevan dengan penelitian. Kata kunci yang digunakan peneliti dalam pengumpulan data adalah Perkembangan E-Learning Sebagai Inovasi Pembelajaran Di Era Digital.

\section{HASIL PENELITIAN DAN PEMBAHASAN \\ Pola atau Sistem Informasi E-learning}

Siragusa (2000) mengidentifikasikan elemen desain instruksional dalam $e$ learning yaitu:

1) Content. Konten meliputi materi yang peserta didik butuhkan dan dalam bentuk alternatif. Karakteristik dasar dari e-learning adalah isi informasi yang tidak selalu berurutan dan fasilitas untuk menghubungkan informasi yang secara konsep masih berhubungan.

2) Interaction. Interaksi antara pendidik dan peserta didik akan membentuk dasar dari komunikasi pembelajaran. Lingkungan pembelajaran yang efektif, 
termasuk e-learning harus memiliki aspek interaksi di antara peserta didik, materi, dan pendidik.

3) Feedback atau umpan balik, adalah yang paling sering disebutkan dalam pembelajaran e-learning. Pembelajaran e-learning menyediakan banyak kesempatan untuk menciptakan umpan balik yang bermakna bagi peserta didik. Mereka dapat melihat hasil kerja online satu sama lain sebagai perbandingan dan menawarkan umpan balik ke rekannya. Model kuis online bahkan mampu memberi umpan balik secara langsung dan sumber terkait materi untuk studi lebih lanjut.

4) Interface design. Tujuan utama dari pembelajaran e-learning yaitu memberi kemudahan dan menjembatani kekurangan dari pembelajaran konvensional terutama keterbatasan ruang waktu. Oleh karena itu desain yang digunakan harus interaktif, mempermudah dan responsif terhadap kebutuhan pengguna. Belajar menggunakan web misalnya, materi dapat dilihat secara masif di satu tempat seperti ruang kelas, dapat dihapus dan diubah tanpa menimbulkan sampah penggunaan.

5) Students involvement. Pendidik yang aktif akan memberikan suasana pembelajaran yang lebih menyenangkan. Aktif bukan berarti teacher centered namun aktif melibatkan siswa dalam pembelajaran, sehingga desain instruksional e-learning harus menarik minat siswa baik melalui bentuk atau interaksi yang dikembangkan oleh pendidiknya.

Dari elemen instruksional tersebut setidaknya dalam merancang e-learning harus mencakup aspek-aspek tersebut. Secara garis besar model-model pembelajaran e-learning dapat digambarkan sebagai berikut.

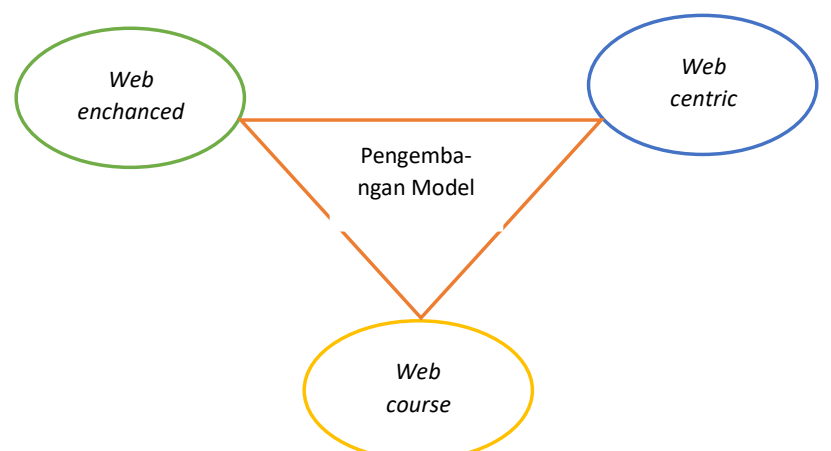

Gambar 1. Model-model e-learning (Rusman, Kurniawan \& Riyana, 2012) 
Web course adalah pemakaian internet untuk keperluan pendidikan dimana pendidikan dan peserta didik sepenuhnya terpisah dan tidak diperlukan adanya tatap muka secara langsung. Seluruh materi bahan ajar, diskusi, konsultasi, ujian dan penugasan dilakukan jarak jauh atau distance learning.

Web centric course adalah pemakaian internet untuk memadukan pembelajaran jarak jauh (distance learning) dengan tatap muka. Caranya dengan sebagian materi disampaikan melalui internet, sebagian lagi melalui tatap muka dan fungsi keduanya saling melengkapi. Pendidik juga memberi arahan untuk peserta didik supaya mencari sumber lain yang relevan, dan dalam kegiatan tatap muka lebih difokuskan pada kegiatan diskusi tentang temuan materi yang dipelajari melalui internet tersebut.

Web enhanced course adalah pemakaian internet untuk memberikan pengayaan sebagai sarana penunjang kegiatan pembelajaran di kelas. Peran pendidik dalam hal ini dituntut untuk menguasai teknik mencari informasi di internet, membimbing mahasiswa mencari dan menemukan situs-situs yang relevan dengan bahan ajar, menyajikan materi melalui web yang diminati, melayani bimbingan dan komunikasi melalui internet dan kecakapan lain yang diperlukan.

Pembelajaran e-learning sangat beragam dan saat ini memiliki banyak bentuk pengembangan sehingga pola sistem informasi juga menyesuaikan dengan penerapan model e-learning tersebut. Andersson (2011) menggambarkan model interaksi e-learning sebagai berikut. 




Gambar 2. E-learning model (Andersson, 2011)

Gambar 2 menjelaskan ilustrasi dua pelaku utama dalam pembelajaran yaitu pendidik dan peserta didik serta interaksi yang terjadi diantaranya. Interaksi terjadi di dalam komunitas inquiri menggunakan komunikasi berbasis web (asynchronous or synchronous) seperti video, chat, computer conference, dan interaksi virtual lainnya). Lingkungan yang timbul memungkinkan bagi peserta didik belajar secara kolaboratif dan mengembangkan hubungan personal diantara pemakai. Pada model sebelah kanan menggambarkan independent learning, bentuk yang paling umum dijumpai yaitu search \& retrieval, tutorials, simulations \& games, virtual labs, e-books.

Tiga bentuk umum interaksi dalam pembelajaran online menurut Aziz (2015) yaitu antar peserta didik-peserta didik (student-student), peserta didikpendidik (student-teacher), dan peserta didik-materi/konten (student-content). 
Kemudian berkembang lagi pendidik-pendidik (teacher-teacher), pendidikmateri/konten (teacher-content), dan materi-materi (content-content), diilustrasikan sebagai berikut.

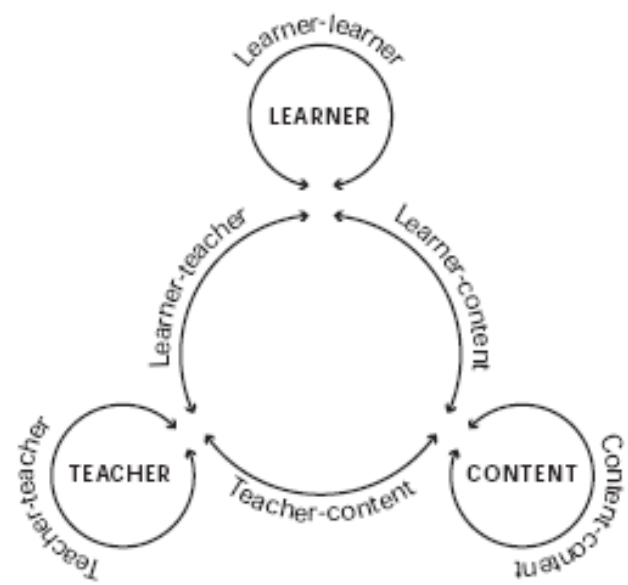

Gambar 3. Interaksi pembelajaran online (Aziz, 2015)

\section{Penerapan E-learning}

Penerapan e-learning dalam pembelajaran saat ini sudah banyak dijumpai dalam berbagai sistem pendidikan di dunia, sedangkan di Indonesia masih terbatas pada wilayah yang menjadi pusat pemerintahan, sedangkan pada sebagian besar daerah belum dapat menerapkan e-learning karena terkendala faktor saranaprasarana serta sumber daya manusia. E-learning secara mutlak harus didukung oleh keberadaan fasilitas seperti instalasi listrik dan jaringan internet. Berikut ini merupakan beberapa contoh bentuk e-learning menurut Horton (2006:2).

1) Standalone courses, yaitu kursus yang diambil oleh peserta didik individu, tanpa interaksi instruktur ataupun teman belajar. Peserta didik mencari sendiri materi bahan ajar tanpa didampingi oleh pendidik.

2) Virtual-classroom courses, yaitu metode pembelajaran yang menggunakan ruang kelas virtual atau non fisik antara pendidik dengan peserta didik. Virtual classroom menghubungkan kelas konvensional dan world wide web (WWW) dengan cara menciptakan struktur dan pengalaman pembelajaran seperti di kelas. Bedanya yaitu virtual classroom tidak harus berada di satu tempat yang sama secara fisik. Pendidik atau instruktur memandu peserta didik dan berinteraksi melalui e-mail, forum diskusi, chat, polling, 
application sharing, konferensi audio dan video, dan alat berkirim pesan virtual yang lain.



Gambar 4. Desain Virtual classroom (Horton, 2006)

Horton (2006:417) menambahkan bahwa ada tiga lingkup yang saling tumpang tindih dalam virtual classroom yaitu: (1) virtual-classroom courses, yang merupakan campuran dari kegiatan synchronous dan asynchronous; (2) online meetings atau webinars, yang merupakan kegiatan synchronous dan bagian dari virtual-classroom course, dan (3) online presentations yang merupakan bagian dari online meetings atau pun sebagai kegiatan yang terpisah. Online presentations tidak interaktif dan kemungkinan disampaikan secara live atau direkam dan dimainkan setelahnya.

Virtual classroom mempunyai beberapa manfaat dalam pembelajaran yaitu: (1) instuktur atau pendidik dapat mengadaptasi pembelajaran ke peserta didik. Instruktur dapat memberi jawaban secara langsung dan menyesuaikan konten materi presentasi lebih cepat sesuai kebutuhan; (2) membentuk komunitas dan disiplin yang dibutuhkan. Pendidik dapat memonitor peserta didik melalui virtual classroom sesuai jadwal dilaksanakannya pembelajaran; (3) pembelajaran berbentuk kelas familiar bagi peserta didik; (4) pembelajaran menjadi lebih fleksibel dan aktif.

3) Learning games and simulations, belajar melalui permainan dan simulasi merupakan hal yang menyenangkan peserta didik seperti kuis, tebak-tebakan, teka-teki dan lain sebagainya. Permainan dan simulasi memungkinkan peserta 
didik untuk melaksanakan tugas, menerapkan pengetahuan, dan menemukan prinsip, sambil bersenang-senang.

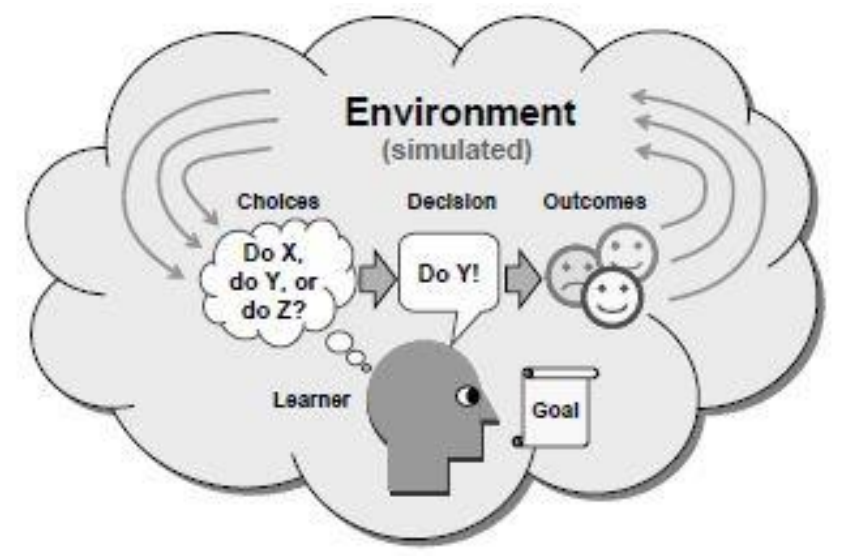

Gambar 5. Model learning games and simulations (Horton, 2006)

Dalam menerapkan pembelajaran dengan permainan dan simulasi, pendidik adalah memegang peran paling penting karena menyusun model permainan dan simulasi yang disukai, namun tanpa melupakan tujuan pembelajaran. Akan tetapi, model pembelajaran ini tidak selamanya cocok digunakan pada berbagai kondisi. Horton (2006:145) kemudian mendefinisikan saat yang tepat menggunakannya yaitu: (1) Saat pembelajaran dengan kondisi sebenarnya tidak praktis atau membutuhkan waktu yang lama, contohnya mempelajari daur hidup hewan dan percobaan pengujian pesawat Boeing terbaru; (2) Resiko untuk kegagalan terlalu tinggi, contohnya belajar membedah otak, belajar mengoperasikan pembangkit tenaga nuklir; (3) Peserta didik membutuhkan perhatian individu, sehingga pendidik dapat menyesuaikan jenis permainan yang sesuai karakter peserta didik; (4) Banyak pihak yang perlu diedukasi; (5) Tugas yang rumit sedangkan waktu terbatas; (6) Keterampilan yang akan diajarkan sifatnya kompleks; (7) Pendidik mempunyai waktu dan dana untuk mengembangkan permainan atau simulasi.

4) Embedded e-learning atau e-learning yang ditanamkan. Selain berdiri sendiri, e-learning dapat juga ditanamkan pada sebuah program komputer seperti menu online help dalam suatu program, dalam prosedur diagnosa, atau dalam sumber informasi elektronik lainnya. E-learning yang berdiri sendiri lebih sederhana untuk dikelola, tetapi e-learning yang ditanamkan dapat diintegrasikan dengan user interfaces, help files, dan bantuan lainnya. Saat 
yang tepat untuk menggunakan embedded e-learning yaitu ketika diagnosa pemecahan masalah membutuhkan pengetahuan yang rinci dan detail.

5) Blended learning. Dalam upaya menghadapi kesulitan tujuan pembelajaran, seringkali pendidik harus mencampur atau blend berbagai media, strategi instruksional, dan pendekatan desain. Hal ini lah yang disebut dengan blending. Definisi blended learning menurut Norm (2012) adalah program pendidikan, baik formal maupun non-formal, yang mengkombinasikan media digital dengan metode pengajaran konvensional. Menurut blendedlearning.org (2017), blended learning adalah sebuah program pendidikan formal dimana peserta didik mengkombinasikan belajar sebagian secara online, sebagian terpisah di rumah, dan sepanjang jalur belajar. Sehingga dapat diartikan bahwa blended learning adalah pembelajaran yang difasilitasi dengan kombinasi efektif dari berbagai model pengajaran, gaya belajar, dan media yang bertujuan menciptakan lingkungan pembelajaran bermakna. Kombinasi tidak hanya dilakukan dengan pembelajaran e-learning dengan pembelajaran ruang kelas, tetapi juga dimungkinkan mengkombinasikan semua bentuk pembelajaran.

Model blended learning menurut Christensen, Horn \& Staker (2013) dibagi menjadi empat sebagai berikut:

(1) Rotation model, dimana peserta didik melakukan pembelajaran dengan belajar online secara mandiri ditambah belajar secara face-to-face di ruang kelas. Terdapat beberapa sub-kelas rotation model yaitu: (a) Station rotation, model ini menekankan pada peserta didik yang bergilir antara berbagai jenis model di dalam kelas, dan setidaknya salah satu model tersebut mengandung komponen pembelajaran online; (b) Lab rotation, hampir sama dengan sebelumnya, bedanya pada komponen pembelajaran online berlangsung di laboratorium pembelajaran; (c) Flipped classroom, peserta didik bergantian menggunakan pembelajaran tatap muka di kelas selama jam belajar dikombinasikan pembelajaran online di luar jam belajar sekolah. Peserta didik mengontrol bagaimana, kapan, dan dimana mereka menerima pembelajaran online, kemudian berganti pada 
lingkungan tatap muka di kelas lagi pada hari berikutnya; (d) Individual rotation, peserta didik mengatur bagaimana mereka berganti model pembelajaran antara tatap muka dengan pembelajaran online.

(2) Flex model, sebagian besar kurikulum disajikan dalam bentuk digital dan pendidik berperan sebagai pembimbing/konsultan yang siap bertemu tatap muka untuk kegiatan pembimbingan.

(3) A La Carte model atau Self blend model, peserta didik mendesain sendiri pengalaman belajar mereka dengan memilih tambahan kursus online apa yang dibutuhkan untuk melengkapi pembelajaran tatap muka konvensional mereka.

(4) Enriched-Virtual model, peserta didik menyelesaikan seluruh kelasnya secara online sedangkan pendidik memandu secara virtual dengan menyediakan bimbingan dan materi secara online.

6) Mobile learning atau M-learning, yaitu pembelajaran multi konteks, melalui interaksi konten dan sosial, dengan menggunakan perangkat smartphone. Fokus dari M-learner adalah mobilitas dari pemakai, menggunakan fungsi dari perangkat mobile untuk membantu mencari atau menciptakan materi yang penting dalam proses pembelajaran.

\section{SIMPULAN}

Blended learning dilaporkan lebih efektif dibandingkan hanya pembelajaran face-to-face atau tatap muka dan hanya pembelajaran online saja. Dengan menkombinasikan sarana digital dan pembelajaran tatap muka, peserta didik dapat bekerja sesuai kreativitasnya dengan konsep baru, dimana pendidik lebih leluasa mendukung peserta didik secara individu (Saritepeci, 2015). Selain itu juga bermanfaat dalam mengurangi pengeluaran pendidikan meskipun sebagian berpendapat bahwa pembelajaran konvensional lebih hemat biaya.

M-learning nyaman digunakan oleh siapa saja, berbagi hampir secara instan diantara semua orang yang mengakses, yang mengarah kepada instant feedback dan tips. M-learning juga mampu menggantikan keberadaan buku melalui 
kemampuan membaca $e$-book, bahkan saat ini dapat digunakan untuk membuka dokumen yang ada di komputer atau laptop

\section{DAFTAR PUSTAKA}

Andersson, T. (2011). Theory and Practice of Online Learning, Fifth Edition. Edmonton, Canada: AU Press Athabasca University.

Aziz, M. A. A. (2015). Proven methods to enhance e-learning process using social media (materials, interaction, and competitive advantage). International Journal of e-Education, e-Business, e-Management and e-Learning. 5 (1), pp. $40-46$.

Blendedlearning. (2017). What is Blended Learning?. Diperoleh dari https://www.blendedlearning.org/basics/, pada tanggal 5 Desember 2017.

Christensen, S., Horn, M. B. \& Staker, H. (2013). Is K-12 Blended Learning Disruptive: An Introduction to The Theory of Hybrids. Clayton Christensen Institute. Diperoleh dari http://bit.ly/1ufTtgZ, pada tanggal 5 Desember 2017.

Darmawan, D. (2014). Pengembangan E-learning, Teori dan Desain. Bandung: PT Remaja Rosdakarya.

e-Learning Africa. (2011). Elearning and Schools. Diperoleh dari www.elearningafrica.com/newsportal/english/news257.php, diakses tanggal 29 November 2017.

Fombona, J., Sevillana, A. P., Videgaray, G \& Carmen, M. (2017). M-Learning And Augmented Reality: A Review Of The Scientific Literature On The Wos Repository. Comunicar (in Spanish).

Horton, W. K. (2006). E-learning by Design. San Fransisco: Pfeiffer.

Male, G. \& Pattinson, C. (2011). A Socio-Cultural And Technology Perspective Towards Quality E-Learning Applications. Campus-Wide Information Systems.

Marshall, S. J. (2012). An analytic framework to support e.learning strategy development. Campus-Wide Information Systems. Vol 29 No 3.

Norm, F. (2012). Report: Defining Blended learning. Diperoleh dari http://learningspaces.org/papers/Defining_Blended_Learning_NF.pdf, pada 5 Desember 2017.

Ossiannilsson, E. S. I. (2012). Quality Enhancement On E-Learning. CampusWide Information Systems. Vol 29 No 4.

Rusman, Kurniawan, K. \& Riyana, C. (2012). Pembelajaran Berbasis Teknologi Informasi dan Komunikasi, Mengembangkan Profesionalitas Guru. Jakarta: PT RajaGrafindo Persada. 
Perkembangan E-Learning Sebagai... (Rochman Hadi Mustofa, Henni Riyanti)

Saritepeci, M. \& Cakir, H. (2015). The Effect Of Blended Learning Environments On Student Motivation And Student Engagement: A Study On Social Studies Course. Education and Science.

Siragusa, L. (2000). Instructional Design Meets Online Learning In Higher Education. Australian Journals of Educational Technology. Vol 27 No 13.

Tham, C. M. \& Werner, J. M. (2005). Designing And Evaluating E-Learning In Higher Education: A Review And Recommendations. Journal of Leadership \& Organizational Studies. Vol 11 No 2.

Zed, Mestika. (2003). Metode Penelitian Kepustakaan. Jakarta: Yayasan Obor Indonesia. 